\title{
Research Into the Improvement of College Students' Life-Long Learning Ability
}

\author{
Xinxin Wang, Qingxi Hu \\ College of Humanities, Arts and Social Science, China University of Petroleum-Beijing, Beijing, China \\ Email: shangdongwangxinxin@163.com, qingxihu@sohu.com
}

Received 2012

\begin{abstract}
The world has been always changing fast in such a wild pace that we will soon be left behind without continuous learning and developing which means it is absolutely necessary to be life-long learner for us in 21 st century. The construction of life-long education system and society with learning atmosphere is a vital goal for the future development and reform on education in 20 years in China. The aim of this study is, while analyzing the necessity of the students' life-long learning (LLL) ability, to put forward some feasible and concrete measures which can improve the life-long learning ability of college students.
\end{abstract}

Keywords: Lifelong Learning; College Students Education; Education Reform

\section{Introduction}

Life-long education, a "Copernican revolution" in the field of education, is the modern education trend which influences the development and reform of the world education extensively and profoundly. It is an inevitable requirement for contemporary science and technology, economics, culture and highly social development. Once it has been put forward, "Lifelong education" with a new educational concept and abundant education connotation overturned people axiology on traditional education. The school education in the 21st century has to adapt to these changes and challenges mentioned above to meet the professional change in the process of social reform and the economic development. The university should pay attention to the cultivation of the students' life-long learning ability which teaches students how to study, think, innovate, survive promising, so that the learners can keep learning in their later life.

The construction of the lifelong education system is a rational demand of the development of times. The dazzling changes in science and technology today gave rise to a rapid increase in the amount of information and caused some site-specific information to lose their up-to-datedness in a fairly short time. Information is a life style, a form of thought and life in an information society. In such a period, the production and use of valid information is important. And the individual who is able to learn is one characteristic of the information society. Learning is becoming a kind of decisive factors that promotes the development of society and economics, boosts the progress of human civilization and the comprehensive development of people. With the rapid development of knowledge revolution, the total amount of knowledge is increasing sharply with geometric and the updated speed of knowledge accelerated dramatically. One-time learning, traditional concept that goes all the day, study, employment and life pattern have been behind, and LLL is becoming the basic need for subsistence and development.

According to some researches, school education received accounts for only about $10 \%$ of a man's necessary knowledge, of which the remaining $90 \%$ will be received while working.
For this reason, one of the new paradigms accepted both in higher educational institutions and -in general- in the entire educational system today is 'lifelong learning'. As a high-level training institution, higher schools have the responsibility to strengthen and develop the students' LLL ability which is a central part advancing the higher education quality. While the lifelong education and LLL are becoming a social trend, the improvement of college students' ability, especially LLL ability, will help students to work and live better. LLL helps people to achieve other goals, such as taking an active part in civic life, leading a more sustainable lifestyle, and improving their health and wellbeing.

\section{Definition of LLL}

Generally speaking LLL means that learning should take place at all stages of life cycle (from the cradle to the grave) and, in more recent versions that it should be life-wide; that is embedded in all life contexts from school to workplace, the home and the community. With the development of the idea and practice of lifelong education, there are some definitions for LLL stated in the following:

- Lifelong learning is a process in which individuals retain their development of knowledge, skills, and interest in their lives and opportunities of learning(Richardson, 1978) which deepens the theory of lifelong education from the standpoint of the educates. The main aim of LLL is to reinforce and improve the life quality of individuals by enabling them to bring their own potential to the utmost level.

- $\quad$ LLL is thought as involving all tactics that are put in place to created opportunities for people to learn throughout life. It should be a process of conscious continuous learning that goes throughout one's life and directed towards offering both the individual needs and that of the relevant community, that will not only develop individuals to become responsible to themselves and their communities, but understand and involve actively at all levels of their societies (Abukari, A., 2004). 
- $\quad$ Learning in which a person engages throughout his or her life. It includes but is not limited to learning that occurs in schools and formal educational programs (Idahoe, 2009). Therefore Lifelong learning is the process of learning which occurs throughout all one's life. In this case, LLL refers to formal and informal learning.

\section{Features of LLL}

European Commission sums up the lifelong learning ability as” the eight key abilities" in the communiqué of 《Modernization of the education and training: for Europe's prosperity and social harmony 》, saying that "the eight key abilities are core skills, knowledge and attitude that must be mastered by each European while making a hit in the knowledge society and knowledge economics.” These abilities are listed as follows:

- $\quad$ Ability to communicate with native language;

- $\quad$ Ability to communicate with foreign language;

- $\quad$ Primary ability in mathematics, science and technology;

- Information technology ability;

- Ability to study;

- Interpersonal and cross-cultural communication ability, citizen accomplishment;

- Work spirit;

- Cultural expression.

So LLL ability, not only gives an eye to man's whole life, but also covers all the aspects of the human development, is such a ability that enable learners active, positive, creative, and comprehensive. To put it in other words, the individuals should be equipped with the basic information and skills for the sake of better understand and process information, and should be able to render the learning process more productive for themselves. Without these skills, either the possibility of learning decreases; or one can learn less with more effort.

In this respect, some of the features of LLL can be summarized as follows:

- $\quad$ Subjectivity: LLL emphasizing conscious learning activities of individual and autonomy learning is that learners, the center of lifelong learning, choose the time, place, and style for learning according to their own needs and take the learners' demand as the orientation.

- Continuity: LLL includes a process from 'cradle to grave' without constraining it to specific time periods, organizations or institutions.

- Multiple integration: LLL runs through not only the whole of one's life longitudinally, but also all the aspects of learning, connects the school study, family study, social learning and other occasions of the study together, which is also multiple integration of stereo.

- Purpose: Lifelong learning emphasizes the individual role in the process of life-long learning. In other words, conscious learning arranged by individual intentionally is more valuable. A lifelong learner has a continuous aspiration for learning and the responsibility for his/her own learning.

- Creativity: Lifelong learning requests learners to adjust their own learning goals, study contents, learning strategies, learning methods, to ensure the pertinence of learning and improve the learning effects. Key notions related to LLL are as follows: individuals' ownership of the need for and the content of learning, related to the way for thinking rather than what to think about.

\section{Schools and Lifelong Learning}

The traditional education is that higher education is the culmination of education, which can provide benefit to the people of the knowledge that will be used in their entire life which means traditional higher education lays stress on "knowledge teaching", a kind of "professional education" or "discipline education". Lifelong education widens the field of vision for people from the traditional school education and expands the extension of education greatly. The school education is not the end, but the beginning of lifelong due to the saying "studying from the cradle to the grave", The report announced in "higher education of the developing countries "by World Bank in 2000 points out that higher education is the fundamental basis education in the modern world, which is no longer a luxury but a taste.

Colleges and universities are the fatal part and core force to construct the lifelong education system and create the learning society as the "producers, wholesalers and retailers" of knowledge, which carries a big weight in producing, accumulating, spreading and applying knowledge. However, just as Christopher 'K, Poole and Arthur` J. Cropley said, we tend to think that carrying out the best solution of lifelong education will be realized by designing the special plan for adult education and providing time to achieve learning opportunities, while ignoring the fact that the main body of students in institution of higher education are still traditional full-time college students entering into the institutions of higher learning directly from the middle school. It is the main mission for the higher school to prepare themselves for bigger tasks prior to life-long learning which is not only a significance to people's modes of learning, but also their learning contents. Facing to turbulent waves of lifelong education and the learning society, colleges and universities must vary as the traditional teaching notion changes referring the instruction of knowledge as their responsibilities, and put forth efforts to foster student's LLL ability. Iman, the UNESCO assistant officer, points out that the concept of learning to study means that the educated people will know where they can quickly and accurately find what they really don't know. It is estimated that $80 \%$ of the time is used to impart knowledge and the remaining $20 \%$ of the time is used to acquire the learning methods and research techniques. This situation will definitely be changed in the future in education system at all levels, especially in higher education stage. The rapid spread of information will necessitate individuals who are able to know how and where to obtain information, and who are selective in their choice rather than all-knowing individuals, in other words, there will be a need for individuals who are able to learn learning (Numanoglu, 1999).

\section{Discussion}

Model of instruction should give priority to learners. In a lifelong learning oriented school, some of the basic factors are putting the student and his/her needs into the centre, a self-directed learning through learning how to learn, and life cycle (Bryce \&Withers, 2003). Higher schools should change their main direction from education of imparting knowledge to developing learners' learning ability which means learn to study, learn to behave, learn to live and learn to develop. In order to 
achieve this, a skill-based curriculum and supportive educational programs should be prepared as well. So colleges and universities should shift traditional teaching methods which centers around the teachers, classrooms and teaching materials to advocate participatory teaching. They should also inspire students to think for themselves, pay special attention to develop the students' innovation spirits, develop their ability to acquire and apply knowledge and information, develop the ability of independent thinking ability and the innovation ability in the teaching activities, so that they can get the necessary knowledge and skills to be used while they participate in the change economic development and the social life. In addition, colleges and universities should not only carry out various kinds of extracurricular activities that make the best of positive roles of all kinds of professional clubs, folk groups and other informal organization, but also improve the students' self management ability, organization skills and explored consciousness on their own initiative. In short, in the most general sense, schools should be organized in such way as to provide students with social skills, learning skills and life skills, and the skill of how to seize opportunities.

Attach importance to apply to the new technology of science and technology. Specifically, in order to develop learning skills, the use of educational software and modern information and communication technologies at schools, and the use of national and international nets should be encouraged (Bryce, Frigo, McKenzie, Withers, 2000). Modern information technology has found an increasingly wide utilization in the field of education, especially with the development of education network, which have broken through the space and time limitation of school education and provided unprecedented materials and technical conditions so that everybody can study in everywhere ever and again flexibly. On the one hand, colleges and universities must carry out the information and technology education to improve the students' information literacy. On the other hand, they should develop network technique and distance education while taking full advantage of modern information technology means including computer technology, network technology and multimedia technology.

The main term in the realization of LLL activity is information literacy, as information society consists of individuals who learn all their lives. Those who learn all their lives long are able to employ the information easily that is needed for solving a problem or making a decision. Information literacy which is a skill of obtaining, using, and conveying information is the basis of lifelong learning. In order to put the principals of LLL ability into practice, we need to encourage individual and social development, and also master a computer-based world (Knapper and Cropley, 2000). To sum up, for a lifelong learning, social environments should be created in which individuals are given the opportunities to develop themselves both personally and socially, and individuals should be rendered competent in computer literacy as dictated by the needs of information society.

Make the most of abundant resources of the school library. School libraries which possess many special points of superiority such as abundant literature materials, flexible learning styles, warm and thoughtful navigation service of information and convenient places to study and so on, have proved to be important places of LLL. The colleges and universities should adhere to the principle of the supremacy for readers and cater for learners in real earnest. First of all, the libraries should train the student of their scientific reading methods. In the next place, the libraries should provide some professional instructional bibliographies timely and effectively for the students to help them to solve the problems in the process of studying and life. Finally, the school libraries should do more efforts in the cultivation of the readers' accomplishments of information, such as giving a lecture about retrieval information to students regularly, designing and making a good library homepage of this school, recommending excellent websites about education to the students and so on.

LLL results from integration of formal, non-formal, and informal learning to create ability for continuous lifelong development of quality of life. In the past, education meant formal educational institutions that served people within a certain time period; on the contrary, in the information age the existence of educational/teaching environment without regard to time and place prevails. Formal learning includes but is not limited to participation for, post high school education provided by colleges and universities; community, military or occupationally sponsored programs; professional counseling and proprietary schools. Informal learning includes, but is not limited to, seeking advice from an expert, experienced peer or adult; using a library or other resource centre and setting up a self-directed learning project -leading toward valuing LLL (Pongratz, 1996).

At present, continuing education are found in many universities which has become the important component of the common university in China while becoming to be the main force carrying out continuing education. However, taking one with another, common universities, are still not playing a full role due to problems such as weak initiative, single mode of running a school, narrow avenue of running a school, overall little effects and so on, which means it is still a long time to meet the needs of launching a learning society. Thus, common universities should be charged with more responsibilities of education for adults after graduating from universities. Colleges and universities should reform the personnel training mode, promote to set up the educational mechanism of combining learning with research and production, strengthen the communication between education and non-academic education and expand social learning opportunities. The ability to cater for the development of the economics and the society has to be enhanced for universities enabling themselves to be important carriers of lifelong learning. Ultimately colleges and universities should open up new curriculums and teaching materials which reflect the new knowledge and technology combine the teaching contents with the reality of production and life together quickly.

\section{Conclusion}

In the 21st century, we all need to be lifelong learners. Our world is changing around us in such a frantic pace that if we do not continue to grow and develop; we will soon be left behind. We need to keep our skills sharp and up to date so that we have an edge in all we do (Eggelmeyer, S. 2010).In conclusion, higher education is undertaking the important function to diffuse civilization, train talents, innovate science and technology and cater for the society which take on the lofty and divine mission in the construction of life-long education system. Higher education must emancipate the mind, change the idea to cultivate high quality talents who possess solid foundation, innovative thinking and practice ability. 


\section{REFERENCES}

Abukari, A. (2004). Conceptualising Lifelong Learning: A Reflection on Lifelong Learning. (pp.1-21), 1st International euredocs conference sciences: Transformations experienced by higher education and research institutions in European countries, Paris.

Bryce, J.\&Withers,G. (2003). Engaging secondary school students in lifelong learning. Australia: Australian Council for Educational Research.

Bryce,J., Frigo,T., Mckenzie, P.\&Withers, G. (2000). The era of lifelong learning: Implications for secondary schools. Australia: Australian Council for Educational Research.

Çalık, T\&Sezgin, F.(2005). Globalization, information society and education. Kastamonu Education Journal, 13(1), 55-66.

Colardyn, D. \& Bjornavold, J. (2004). Validation of Formal, Non-Formal and Informal Learning: policy and practices in EU Member States. European Journal of Education, 39 (1), pp.69-89.

Crowther, J(2004). "In and against" lifelong learning: Flexibility and the corrosion of character. International Journal of Lifelong Education, 23(2), 125-136.

Eggelmeyer, S. (2010, November 11). What are the benefits of lifelong learning? Expert Answer. Retrieved 2011 Sep. 30, from: http://continuing-education.yoexpert.com/lifelong-learning/what-arethe-benefits-of-lifelong-learning-445.html.

Hildebrand, D. S. (2008). The powerful benefits of lifelong learning. Winnetka, California; USA, Retrieved 2011 Sep. 30, from:

http://www.officearrow.com/training/the-powerful-benefits-of-lifelonglearning-oaiur-861/view.html.

Idahoe (2009). Glossary, Idaho electronic compus, Idahoe, USA. Retrieved 15 May 2011 from:

http://www.idahoe-campus.state.id.us/tools/glossary.html\#learner.

Knapper,C.K, \& Cropley, A.J. (2000). Lifelong learning in higher education, 3. Ed. London: Kogan Page.

Nordstrom, N. M. \& Merz, J. F. (2006). Learning later, living greater; the secret for making the most of your after-50 years. Colorado; USA, Sentient Boulder CO Publishing.

Numanoglu, G. (1999). Bilgi toplumu-egitim-yeni kimlikler-II: Bilgi toplumu ve egitimde yeni kimlikler.

Pongratz, E.M. (1996). Lifelong learning in young adult literature. Unpublished doctorate thesis, The Pennsylvania State University.

Richardson, P.L.\&others. (1978). Lifelong learning and public policy.Wacshington:D.C.U.S.Government Printing Office. 